\title{
Konflik Kepentingan dalam Liberalisasi Perdagangan Garam Tahun 2009-2014
}

\author{
Esti Renatalia Tanaem¹, Puguh Toko Arisanto ${ }^{2}$ \\ ${ }^{1}$ Wahana Visi \\ ${ }^{2}$ Universitas Teknologi Yogyakarta
}

\begin{abstract}
The trade liberalization of the domestic salt sector in Indonesia indicated by tariff reduction faced pros and cons. Using the concept of two-level games and governmental processes, the authors found a political upheaval of bureaucrats and interest groups adorning the political process in salt liberalization in Indonesia. Political upheaval occurred due to the tug of war between the two opposing parties. The pros, represented by the Ministry of Industry, Ministry of Trade, importers, and mafias, supported salt imports to meet domestic needs that cannot be fulfilled by domestic salt productions, both in quality and quantity. While the cons represented by the Ministry of Marine Affairs and Fisheries and salt farmers - both from associations and non-association - demanded salt import reduction support the domestic salt production program and the sustainability of the domestic salt industries.
\end{abstract}

Keywords: liberalization, salt, two-level games, political upheaval, tug of war

\begin{abstract}
ABSTRAK
Perdagangan bebas dari sector garam domestic di Indonesia ditandai dengan penurunan tarif menuai pro dan kontra. Dengan menggunakan konsep two level games dan governmental process, penulis menemukan adanya pergolakan politik para aktor, baik dari kalangan birokrat maupun kelompok kepentingan yang menghiasi proses politik dalam liberalisasi garam di Indonesia. Pergolakan politik terjadi akibat Tarik ulur antara dua pihak yang bertolak belakang. Pihak pro yang diwakili oleh Kementerian Perindustrian, Kementerian Perdagangan, importir, dan mafia mendukung impor garam untuk memenuhi kebutuhan dalam negeri yang tidak dapat dipenuhi oleh produksi garam dalam negeri, baik secara kualitas maupun kuantitas. Sedangkan, pihak kontra yang diwakili oleh Kementerian Kelautan dan Perikanan serta petani garam - baik dari asosiasi maupun non-asosiasi menuntut pengurangan impor garam untuk mendukung program produksi garam dalam negeri dan keberlanjutan industri garam dalam negeri.
\end{abstract}

Kata Kunci: garam, liberalisasi, pergolakan politik, two-level games, tarik ulur kepentingan 


\section{PENDAHULUAN}

Salah satu bentuk globalisasi adalah semakin mudahnya arus barang dan jasa dari satu negara ke negara lain. Fenomena free flow ini merupakan konsekuensi dengan adanya liberalisasi perdagangan dari satu negara ke negara lainnya. Liberalisasi perdagangan adalah penghapusan atau pengurangan hambatan perdagangan di antara negara-negara. Bentukbentuk liberalisasi perdagangan adalah pengurangan atau penghapusan tarif, pengurangan atau penghapusan kuota, dan pengurangan hambatan non-tarif (Banton, 2019). Sejalan dengan teori perdagangan bebas klasik, liberalisasi perdagangan menekankan pada sistem perdagangan internasional yang terbuka, karena dipercaya dapat membawa kemakmuran bagi negara-negara dunia. Sistem perdagangan tersebut dapat dilihat dari peniadaan hambatanhambatan dalam perdagangan internasional, baik hambatan tarif maupun non-tarif, dengan tujuan agar barang dapat bergerak lebih leluasa dan menyebabkan barang impor yang masuk ke suatu negara dengan lebih mudah.

Liberalisasi perdagangan telah banyak menuai pro dan kontra. Para pendukung liberalisasi perdagangan yakin bahwa dengan meliberalisasi sektor perdagangan maka akan menciptakan kesejahteraan yang belum pernah terwujud sebelumnya (Cho \& Diaz, 2008). Hal ini dikarenakan negara-negara maju membuka pasarnya bagi ekspor yang berasal dari negara-negara berkembang, meliberalisasi pasar mereka, meniadakan hambatan-hambatan birokratis terhadap aliran barang dan jasa dan membiarkan globalisasi bekerja dengan caranya. Akan tetapi, pada kenyataannya liberalisasi perdagangan tidak terlepas dari aspekaspek kontroversial yang hampir menghilangkan manfaat yang ingin dicapai semisal peningkatan efisiensi dan pertumbuhan ekonomi. Timbulnya masalah-masalah seperti upah yang rendah dan hilangnya kedaulatan negara merupakan aspek-aspek kontroversial yang dimaksud (Stiglitz, 2006).

Salah satu contoh implementasi liberalisasi perdagangan adalah liberalisasi sektor garam domestik di Indonesia. Praktik liberalisasi sektor garam di Indonesia tidak bisa dilepaskan dari hasil kesepakatan multilateral pemerintah Indonesia dengan rezim-rezim global seperti World Trade Organization (WTO), Free Trade Area (FTA) dan International Monetery Fund (IMF). Rezim-rezim tersebut dianggap sebagai agen liberalisasi perdagangan di dunia. Liberalisasi sektor garam di Indonesia diimplementasikan melalui kebijakan tarif impor beberapa jenis garam yang mengalami penurunan dari dari 10\% menjadi 5\% menurut Kementerian Keuangan (Kemenkeu). Sementara itu, menurut Kementerian Perdagangan (Kemendag) tarif bea masuk untuk komoditas garam baik untuk konsumsi dan industri tidak dikenakan bea masuk sama sekali atau 0\% (Boenarco, 2012). Dari sini, dapat dikatakan bahwa terjadi liberalisasi perdagangan pada sektor garam di Indonesia karena ada pengurangan dan penghapusan tarif bea masuk untuk komoditas ini terlepas dari adanya perbedaan tarif di antara kedua kementerian tersebut. Berikut tabel penjelasannya: 
Tabel 1. Tarif Bea Masuk Garam Impor

\begin{tabular}{|l|l|l|l|l|l|}
\hline Kode HS & Uraian & BTBMI (\%) & BTKI (\%) & Depdag \\
\cline { 3 - 6 } & & $\begin{array}{l}\text { 2003 \& } \\
\text { sebelum }\end{array}$ & $\begin{array}{l}\text { 2004 } \\
\text { dst }\end{array}$ & 2012 & 2011 dst \\
\hline 25.01 & $\begin{array}{l}\text { Garam (termasuk garam meja dan garam } \\
\text { didenaturasi) dan natrium klorida murni, } \\
\text { dalam larutan air atau mengandung } \\
\text { tambahan bahan anti-caking atau free- } \\
\text { flowing atau tidak: air laut }\end{array}$ & & & & \\
\hline $\begin{array}{l}2501.00 .100 \\
2501.00 .10 .00\end{array}$ & Garam meja & 10 & 5 & 5 & 0 \\
\hline 2501.00 .200 & $\begin{array}{l}\text { Garam dalam bentuk curah atau dalam } \\
\text { kemasan @50 Kg atau lebih dengan } \\
\text { kadar NaCl minimum }\end{array}$ & 0 & - & - & 0 \\
\hline $\begin{array}{l}2501.00 .900 \\
2501.00 .90\end{array}$ & $\begin{array}{l}\text { Lain-lain } \\
\text { Lain-lain: }\end{array}$ & 15 & - & - & \\
2501.00.90.10 & $\begin{array}{l}\text { Mengandung natrium klorida paling } \\
\text { sedikit 94,7\% dihitung dari basis kering } \\
\text { Lain-lain }\end{array}$ & & 0 & 0 & 0 \\
\hline 2501.00 .90 .90 .200 & Garam batu & 10 & 10 & 0 \\
\hline 2501.00 .50 .00 & Air laut & & 10 & 10 & 0 \\
\hline
\end{tabular}

Sumber: Tim Tarif Kementerian Keuangan dan Kementerian Perdagangan dalam Boenarco, 2012.

Sebagai negara dengan garis pantai terpanjang kedua di dunia, Indonesia dianugerahi kekayaan laut yang melimpah dan berpotensi menghasilkan bahan baku pembuatan garam dalam jumlah yang sangat besar. Namun dalam faktanya, tidak lebih dari 10\% dari kekayaan laut Indonesia yang berhasil dikembangkan (Cahaya, 2014). Ironisnya, meskipun kaya dengan potensi garam yang melimpah, dengan adanya liberalisasi perdagangan, Indonesia telah menjadi salah satu negara importir garam sejak tahun 1998. Impor dilakukan karena produksi garam domestik hanya menghasilkan 1,2 ton pertahun sementara kebutuhan khususnya untuk industri mencapai 2,8 juta ton pertahun sehingga untuk memenuhi kekurangannya, Indonesia mengimpor garam dari Australia, India dan Tiongkok (Jamil, 2015). Data lain menyebutkan bahwa Impor garam Indonesia pada tahun 2014 mencapai 2,3 juta ton dari total kebutuhan yang mencapai 3,53 juta ton setiap tahunnya (Salam, 2016). Indonesia juga mengimpor garam dari Selandia Baru, Jerman, Denmark, bahkan dari negara kecil Singapura (Ariyanti, 2013). Padahal secara geografis, Indonesia sebenarnya masih memiliki wilayahwilayah lain yang dapat dimanfaatkan dan dieksploitasi untuk menghasilkan garam dalam jumlah yang sangat besar guna memenuhi kebutuhan domestik, yaitu Madura dan NTT. Hingga tahun 2013, Australia menjadi negara eksportir garam terbesar ke Indonesia dengan nilai sekitar US\$73 juta dollar diikuti India dengan nilai sekitar US\$13 juta dollar (UN Comtrade, 2014).

Berdasarkan data di atas, penulis menilai bahwa implementasi liberalisasi sektor garam di Indonesia melalui transaksi impor garam menyebabkan adanya tarik menarik kepentingan dari berbagai pihak baik di lingkungan birokrat maupun di luar birokrat. Tulisan ini akan menjelaskan tarik menarik kelompok kepentingan di level domestik dalam liberalisasi perdagangan sektor garam di Indonesia dan sebagai sampelnya, penulis akan memfokuskan pada era pemerintahan Presiden Susilo Bambang Yudhoyono dalam rentang waktu 20092014. 


\section{KERANGKA PEMIKIRAN}

Dalam menganalisa permasalahan tersebut, penulis menggunakan teori Two Level of Games milik Robert D. Putnam (1988) yang menjelaskan bahwa politik domestik dan hubungan internasional saling memengaruhi satu sama lain. Interaksi antara level domestik dan internasional tersinkronisasi atas dasar prinsip ekonomi politik yang melandaskan pada bagaimana tujuan politik dan ekonomi yang identik dengan keuntungan dan kepentingan saling memengaruhi. Kebijakan domestik maupun luar negeri yang memiliki implikasi terhadap hubungan luar negeri dikeluarkan oleh suatu negara atas pertimbangan pemenuhan di dua level tersebut. Dalam hal ini, pemerintah suatu negara mendapatkan tekanan internasional maupun tekanan domestik, sehingga tekanan internasional dan tekanan domestik berada pada posisi setara.

Penulis melihat bahwa kebijakan liberalisasi perdagangan sektor garam di domestik dibuat karena kebutuhan dalam negeri yang belum bisa dipenuhi oleh garam rakyat dan kepentingan yang berbeda-beda dari para aktor birokrat maupun kelompok kepentingan. Kebijakan pro dan kontra akibat dari kebijakan impor garam mencerminkan adanya pertarungan kepentingan di antara kementerian-kementerian, yaitu Kementerian Kelautan dan Perikanan, Kementerian Perindustrian, dan Kementerian Perdagangan. Sedangkan, kelompok kepentingan yang berada di luar birokrat berasal dari kelompok petani garam melalui Asosiasi Petani Garam Indonesia maupun petani-petani yang tidak terlibat dalam asosiasi ini, importir dan mafia garam yang mana masing-masing memiliki kepentingan berbeda-beda yang dapat diketahui dari tindakan yang diambil.

Dalam penelitian ini, penulis menerapkan metode penelitian kualitatif yang memudahkan untuk memperoleh gambaran menyeluruh mengenai situasi yang sedang dipelajari. Data yang digunakan berasal dari berbagai sumber kepustakaan, seperti seperti buku, artikel jurnal, skripsi/tesis dan, website di internet. penulis juga melakukan wawancara kepada pejabat terkait di lingkungan Kementerian dan Dinas Kelautan dan Perikanan di Kupang NTT dan beberapa petani garam di tambak di kupang NTT. Penulis juga melakukan observasi lapangan, di beberapa daerah seperti: 1) Tambak Garam Geomembran dan Konvensional di Desa Oeteta, Kecamatan Sulamu Kabupaten Kupang NTT, 2) Tambak garam Dinas Perindustrian dan Perdagangan Provinsi NTT' di Kecamatan Oesapa Barat, 3) Tambak garam milik Dinas Perindustrian dan Perdagangan Kabupaten Kupang di Desa Oeteta

\section{HASIL DAN PEMBAHASAN}

Kebijakan impor garam yang menghasilkan perdebatan pro dan kontra dapat dicerminkan dalam pertarungan kepentingan di antara para aktor, baik yang berasal dari birokrat maupun yang berada di luar birokrat iru sendiri. Kepentingan dan kebijakan aktoraktor tersebut dapat diuraikan sebagai berikut:

\section{A. Kepentingan Kementerian Kelautan dan Perikanan}

Kementerian Kelautan dan Perikanan (KKP) merupakan kementerian yang kontra terhadap impor garam dan mendukung sepenuhnya pemberdayaan usaha garam rakyat untuk memenuhi kebutuhan domestik. Kementerian yang bisa dikatakan sejalan dengan semangat nasionalisme ini menegaskan bahwa swasembada garam nasional bisa tercapai apabila 
pemerintah melakukan pengurangan kuota impor garam secara berangsur-angsur dan meningkatkan produksi garam domestik (Baihaki, 2013). Kementerian ini berupaya untuk memberdayakan masyarakat agar terjadi peningkatan kuantitas dan kualitas dalam produksi. Jika kualitas garam rakyat belum mampu untuk memenuhi kebutuhan industri, maka perlu diinisiasi dengan program peningkatan kualitas garam tersebut. Bagi KKP, pihak yang membutuhkan garam industri seharusnya berkoordinasi dan berkerjasama dengan KKP sehingga usaha memberdayakan garam rakyat juga dapat untuk mencapai kualitas garam industri. Akan tetapi, koordinasi seperti ini tidak dilakukan (Gumilar, 2014).

Kepentingan KKP untuk melindungi industri garam rakyat dapat dilihat dari beberapa contoh pernyataan para pejabat di lingkungan KKP yang pada intinya kontra terhadap impor garam. Di antaranya sebagai berikut:

1. Fadel Muhammad, Menteri KKP dan juga Ketua Yayasan Pemberdayaan Garam Rakyat (YPGR), menyatakan bahwa Indonesia tidak perlu lagi mengimpor garam. Ini dikarenakan Indonesia sudah mampu berswasembada garam konsumsi, walau tidak dengan garam industri. Menurutnya, perbedaan garam konsumsi dan garam industri hanya terdapat pada tingkat kekeringan saja, bukan mengenai masalah kualitas garam lokal yang dianggap jauh lebih buruk dari garam impor. Masalah ini bisa diselesaikan dengan memasang blower. Garam industri dapat dibuat secara bertahap, yakni garam konsumsi diproduksi kemudian garam industri (Nurhayat, 2014). Fadel Muhammad, juga mengecam Kemendag karena tetap mengijinkan impor garam pada masa panen garam rakyat dan hanya memberi izin impor tanpa melakukan pengawasan (Irawan, 2011).

2. Sharif Cicip Sutardjo, Menteri KKP setelah Fadil Muhammad, menyatakan bahwa stok garam konsumsi sudah melebihi kebutuhan, sehingga stok yang berlebih itu dapat digunakan untuk membantu proteksi garam domestik dengan meningkatkan kualitas gudang tempat penyimpanan garam. Menurutnya, kualitas garam konsumsi sudah bagus tinggal meningkatkan $\mathrm{NaCl}$ supaya dapat menyuplai kebutuhan garam industri (Fitria, 2014).

3. Direktur Jenderal Kelautan, Pesisir dan Pulau-Pulau Kecil KKP berargumen bahwa impor garam konsumsi Indonesia adalah akibat dari pihak yang bermain demi keuntungan sendiri padahal sudah mampu swasembada. Pengimpor seolah-olah mengimpor garam konsumsi padahal mengimpor garam industri demi menghindari bea masuk garam industri mengingat tidak ada bea masuk garam konsumsi. Jika pemerintah benar-benar ingin melindungi garam dalam negeri, maka bea masuk garam seharusnya tidak nol, karena itu akan sangat mempermudah pengimpor. Garam rakyat semakin tidak mendapat pasar di ranah domestik (Faisal, 2014).

4. Direktorat Pemberdayaan Masyarakat Pesisir dan Pengembangan Usaha (DIT.PMPPU), salah satu direktorat di KKP, mengungkapkan bahwa garam rakyat telah diproduksi dalam jumlah yang banyak, namun tidak jelas distribusinya sehingga Indonesia masih saja impor garam. Garam yang diproduksi petani garam Indonesia setelah diolah dan dicuci akan menjadi garam industri sehingga grade-nya menjadi bagus. Hal ini berarti bahwa garam rakyat sudah bisa masuk ke garam industri. Selama ini berita yang beredar di masyarakat bahwa garam rakyat belum bisa digunakan untuk industri namun faktanya 
beberapa produk seperti produk minuman dan tekstil telah menggunakan garam rakyat.

Sebagian besar garam geomembran bisa digunakan untuk industri (Gumilar, 2014).

Selain melalui penyataan sikap para pejabat di KKP, perwujudan dari sikap mendukung pemberdayaan usaha garam dilakukan oleh KKP dengan mengeluarkan sebuah program yang disebut dengan PUGAR. PUGAR adalah sebuah program Pemberdayaan Usaha Garam Rakyat yang diinisiasi oleh KKP sejak tahun 2011. Program ini diperuntukkan untuk memperluas lapangan kerja dan meningkatkan kesejahteraan petambak garam rakyat, dan pelaku usaha lainnya dalam rangka menyongsong swasembada garam nasional melalui bottom up-principle (menggunakan mekanisme tugas pembantuan/TP). Selain itu, PUGAR bertujuan untuk: 1) Meningkatkan produktivitas dan kualitas garam rakyat, pendapatan petambak, dan peranan koperasi; 2) Menguatkan usaha kelompok usaha garam (KUGAR) dengan kemitraan/jejaring usaha; 3) Mengoptimalkan sarana dan prasarana produksi dan pengolahan garam rakyat (Apriella, 2016).

Dana PUGAR berasal dari salah satu program pro rakyat dalam pengentasan kemiskinan yaitu Program Nasional Pemberdayaan Masyarakat (PNPM) Mandiri Kelautan Perikanan. Hingga tahun 2014, setidaknya terdapat 43 kabupaten/kota penerima dana PUGAR. Dengan adanya PUGAR, ini menunjukkan bahwa garam yang dulu dianggap komoditas kurang penting menjadi pusat perhatian pemerintah dan mencanangkan swasembada garam nasional 2014 meskipun dikhususkan untuk garam konsumsi.

Melalui observasi lapangan di tambak garam geomembran dan konvensional di salah satu desa di Kupang NT'T, penulis menemukan bahwa masih ditemukannya banyak ketidaksesuaian dalam implementasi PUGAR antara program dengan tujuan yang ingin dicapai misalnya tujuan untuk meningkatkan kuantitas serta kualitas garam namun pada kenyataannya sejak 2011 hingga 2013 tidak ada upaya transfer teknologi agar tercapai kuantitas serta kualitas garam yang ingin dicapai. Baru pada tahun 2014, dengan adanya teknologi geomembran dari program PUGAR, terlihat bahwa masa panen lebih cepat dan kualitas garam lebih baik dari pada hasil garam tambak konvensional. Teknologi geomembran ini memang membutuhkan lebih banyak dana namun memberi keuntungan yang lebih untuk jangka panjang dan lebih sesuai untuk mencapai tujuan dari program ini. Selain PUGAR, KKP juga mencairkan pembentukan sentra-sentra produksi garam di seluruh Indonesia untuk meningkatkan kuantitas produksi, namun usaha ini dan usaha lainnya yang sejenis masih belum cukup berhasil.

\section{B. Kepentingan Kementerian Perindustrian}

Kementerian Perindustrian atau Kemenperin merupakan kementerian yang pro terhadap impor garam khususnya garam industri. Kemenperin bertanggungjawab pada garam industri dan KKP bertanggungjawab pada garam konsumsi. Garam industri masih diimpor sepenuhnya karena kualitas lokal belum bisa dianggap memenuhi kriteria garam industri (Fitria, 2014). Direktur Jenderal Basis Industri Manufaktur Kemenperin, Panggah Susanto menilai bahwa agar dapat mengatasi kekurangan pasokan garam maka harus melakukan impor. Garam industri impor yang lebih disukai karena harga yang lebih murah, kadar air rendah dan lebih bersih. Petani garam didorong oleh pemerintah tapi pemerintah tidak dapat melindungi harga garam (Faisal, 2014). 
Melihat hal tersebut, kritik terhadap kebijakan kementerian Perindustrian tidak jarang digaungkan. Kritikan tersebut merekomendasikan agar Kemenperin melakukan tindakan yang bersifat jangka panjang, yakni adopsi teknologi dari negara yang sudah memiliki kemajuan dalam industri garam dan mengimplementasikannya pada petani garam Indonesia dan dengan begitu dapat meningkatkan daya saing dari petani garam Indonesia.

Berkaitan dengan kebijakan yang pro garam domestik, Kemenperin sendiri sebenarnya juga mempunyai program pengembangan klaster industri garam yang tertuang dalam Peraturan Menteri Perindustrian No.134/M.Ind/Per/10/2009 yang kemudian mengalami perubahan melalui Peraturan Menteri Perindustrian No.88/MIND/PER/10/2014. Program ini sudah ada sejak tahun 2009 jauh sebelum program PUGAR diadakan. Indikator pencapaian pengembangan klaster industri garam ini adalah terpenuhinya kebutuhan aneka industri dan konsumsi garam nasional, meningkatnya produksi garam nasional, menurunnya volume garam impor dan terdistribusinya volume garam beryodium yang memenuhi persyaratan (Kemenperin, 2009). Pengembangan klaster menargetkan selain pemenuhan pasar dalam negeri juga pemenuhan pasar luar negeri dengan bekerjasama antar badan-badan pemerintahan. Selain itu, menurut Undang-Undang ini, Kemenperin menyatakan bahwa perlu mengetahui ketentuan jenis garam yang dapat digunakan sebagai garam industri. Berikut grafik pengelompokkan garam berdasarkan Peraturan Menteri Perindustrian No.88/M-IND/PER/10/2014:

Grafik 1. Pengelompokkan Garam

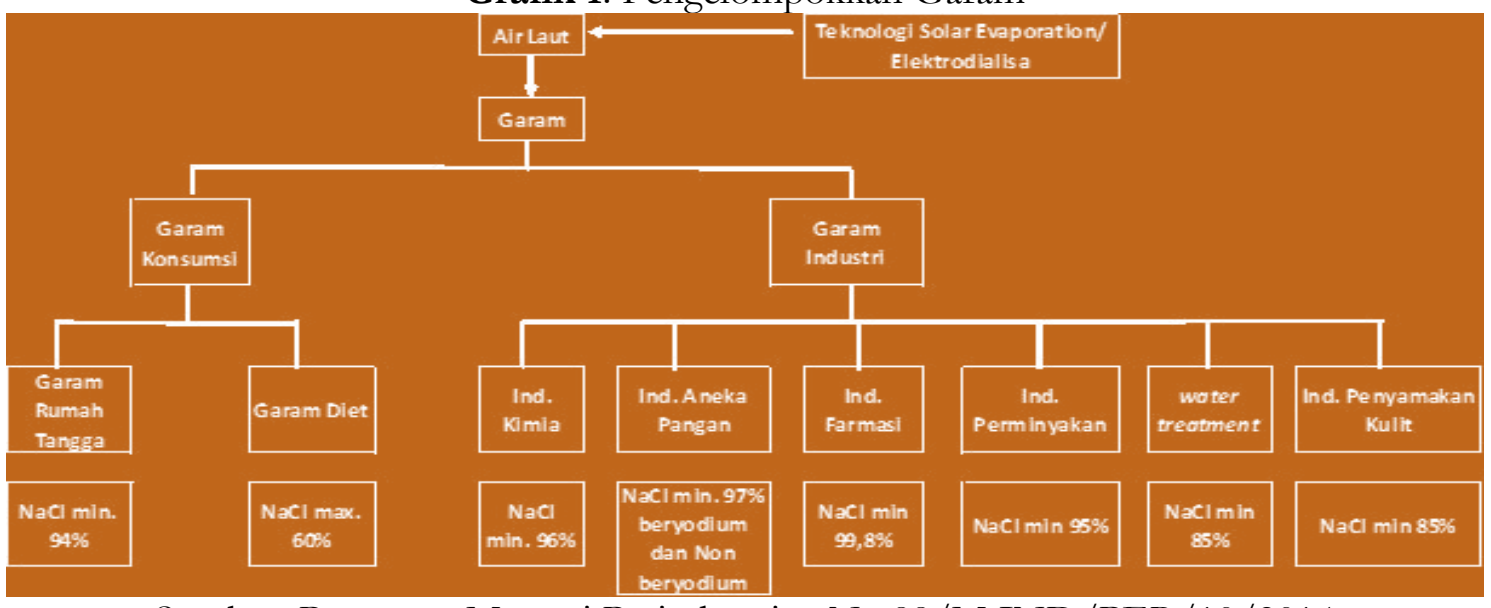

Sumber: Peraturan Menteri Perindustrian No.88/M-IND/PER/10/2014

Meskipun program ini ditujukan (salah satunya) untuk mengurangi volume impor garam industri, namun dalam realitanya berbeda. Kemenperin tetap mengimpor garam industri dengan jumlah yang semakin besar dan beralasan bahwa garam rakyat masih belum dapat mencukupi kebutuhan industri baik secara kuantitas maupun kualitas sehingga garam industri masih impor sepenuhnya. Garam rakyat yang tidak memenuhi standar industri adalah alasan utama Indonesia masih mengimpor garam industri. Hal ini bertolak belakang dengan pernyataan dari KKP bahwa ada beberapa industri yang sudah menggunakan garam rakyat sebagai garam untuk industri mereka dan didukung dengan pernyataan bahwa ketika industri kulit menggunakan garam yang diimpor dari Australia, produk kulit yang dihasilkan membusuk (Baihaki, 2013). KKP menegaskan bahwa tidak benar jika garam rakyat kalah 
secara kualitas industri dari garam impor. KKP juga menyindir bahwa kebijakan impor garam yang juga dikeluarkan oleh Kemenperin sangat bertolak belakang dengan program klaster industri garam Kemenperin yang tujuan akhirnya adalah untuk meningkatkan produktivitas dan daya saing garam rakyat serta pemenuhan pasar dalam dan juga luar negeri.

Berdasarkan hasil observasi dengan pelaku industri garam lokal, penulis menyimpulkan bahwa program Kemenperin mengenai klaster industri sangat bertolak belakang dengan kebijakan impor garam yang juga dikeluarkan oleh Kemenperin. Para petani garam pada dasarnya menginginkan agar pemerintah memilih untuk meningkatkan produktivitas dan daya saing garam rakyat daripada impor garam terus menerus. Jika kedua kementerian (KKP dan Kemenperin) duduk bersama untuk menghasilkan kebijakan peningkatan produktivitas garam yang bersinergi maka hasil yang didapat akan lebih baik. Namun, karena kepentingan yang dimiliki berbeda-beda, kecil kemungkinan untuk hal ini dilakukan.

\section{Kepentingan Kementerian Perdagangan}

Kementerian Perdagangan atau Kemendag juga merupakan kementerian yang mendukung impor garam. Menurut Direktur Jenderal Perdagangan Luar Negeri Kemendag, Deddy Saleh, Indonesia masih terlalu dini jika ingin menghentikan impor garam karena akan terjadi kekurangan stok garam (Raydion, 2012). Kemendag mengeluarkan peraturan mengenai impor garam yaitu Peraturan Menteri Perdagangan Nomor 58/MDAG/PER/9/2012 mengenai impor garam. Pasal 2 ayat I menyatakan bahwa garam yang dapat diimpor hanya garam konsumsi dan garam industri. Hal ini menunjukkan bahwa Kemendag masih memperbolehkan izin impor garam konsumsi dan memegang kendali dalam impor garam baik konsumsi maupun produksi. Berikut merupakan data impor garam Indonesia tahun 2008-2012:

Tabel 2. Data Impor Garam Indonesia 2008-2012

\begin{tabular}{|l|l|}
\hline Tahun & Volume \\
\hline $\mathbf{2 0 0 8}$ & 1.657 .500 \\
\hline $\mathbf{2 0 0 9}$ & 1.701 .410 \\
\hline $\mathbf{2 0 1 0}$ & 2.083 .340 \\
\hline $\mathbf{2 0 1 1}$ & 2.835 .870 \\
\hline $\mathbf{2 0 1 2}$ & 2.223 .090 \\
\hline
\end{tabular}

Sumber: Badan Pusat Statistik, 2013

Data di atas menunjukkan bahwa impor garam Indonesia mengalami kenaikan dari tahun 2008 hingga tahun 2012. Ini juga menjadi sesuatu yang mencengangkan bagi KKP sebagai pihak yang kontra terhadap impor garam ditambah lagi fakta bahwa terdapat kenaikan volume impor garam setiap tahunnya (kecuali tahun 2012 yang mengalami penurunan). KKP mengklaim bahwa tahun 2012 Indonesia seharusnya sudah swasembada garam rakyat sehingga menurut KKP, Indonesia setidaknya bisa menghentikan impor garam konsumsi. Hal ini berdasarkan pada neraca garam nasional tahun 2013 sebagai berikut: 
Tabel 3. Neraca Garam Nasional 2013

\begin{tabular}{|c|c|c|c|c|c|}
\hline \multicolumn{6}{|c|}{ NERACA GARAM NASIONAL 2013} \\
\hline URALW/TAHUN & 2008 & 2010 & 2011 & 2012 & 2013 \\
\hline KEBUTUHAN GARAM & $2,960,250$ & $3,003,550$ & 3.228 .750 & 3.270 .086 & 3.534 .670 \\
\hline A. Garan Konsumsi & $1,160,150$ & 1.200 .800 & 1.426000 & 1466336 & 1527170 \\
\hline a. Rumah Tangga & 700,000 & 720.000 & 747000 & 732645 & 742170 \\
\hline b. Industri Aneka Pangan & 160.150 & 165.800 & 209000 & 282000 & 285000 \\
\hline c. Industri Pengasinan lkan & 300,000 & 315,000 & 410.000 & $45 t 691$ & 500000 \\
\hline B. Garam Industri & $1,800,100$ & 1,8002750 & 1.802750 & 1803.750 & 2027.500 \\
\hline a. Industri CAP & $1,600,000$ & $1,600,000$ & $1,600,000$ & 1601000 & 1822500 \\
\hline $\begin{array}{l}\text { b. Industri NON CAP } \\
\text { (kuiti, tekstil, sabun, dsb.) }\end{array}$ & 200,100 & 202,750 & 202750 & 202750 & 205000 \\
\hline PRODUKSI GARAM & $1,371,000$ & 30,600 & 1.1133.118 & 2071.601 & $701.61^{\circ}$ \\
\hline A. Garam Konsumsi & $1,371,000$ & 30.600 & 1113118 & 2071.601 & 701.671 \\
\hline B. Garam Industri & 0 & 0 & 0 & 0 & \\
\hline
\end{tabular}

Sumber: Ditjen KP3K via Gumilar, Dinas Kelautan dan Perikanan Kabupaten Kupang, 2014.

Meskipun demikian, Kemendag tetap melakukan impor sebesar 533.000 ton dengan tujuan memenuhi kebutuhan garam konsumsi (Detikfinance, 2012). Plh Direktur Jenderal Perdagangan Luar Negeri mengatakan kebijakan ini adalah hasil rapat antara pihak Kementerian Luar Negeri dengan Dirjen Manufaktur Kemenperin yang dibahas melalui rapat koordinasi

Menurut Bank Dunia, di sektor pertanian produk sensitif seperti beras, cengkeh, garam, gula, jagung, dan kedelai telah dikenakan perizinan impor khusus. Oleh karena garam merupakan salah satu komoditas penting di bidang pertanian dan menjadi salah satu yang dilindungi oleh pemerintah, maka dapat dikatakan bahwa garam adalah bagian dari komoditas sensitif dan perlu diberlakukan perizinan impor khusus, yaitu masa dimana impor garam tidak boleh dilakukan dan ada kuota yang membatasi jumlah impor garam setiap tahunnya (Baihaki, 2013). Akan tetapi peraturan-peraturan ini kerap dilanggar sendiri oleh Kemendag selaku pembuat peraturan mengenai impor garam. Semisal di tahun 2011, panen raya disepakati pemerintah dilaksanakan pada Agustus hingga Oktober artinya garam impor dilarang masuk pada bulan Juli hingga Desember 2011. Kenyataannya, hingga Agustus garam impor tetap masuk. Menurut Kemendag dan Kemenperin, hal ini terpaksa dilakukan karena garam lokal tidak mencukupi (Rizal, 2011).

Menurut Wakil Ketua Umum Kamar Dagang Indonesia (Kadin) bidang Perdagangan, Distribusi dan Logistik, Natsir Mansyur, komoditas pangan terdapat banyak kepentingan politik didalamnya mulai dari partai politik, pengusaha dan kepentingan individu. Ada mekanisme yang tidak berjalan sebagaimana mestinya yang terlihat dalam contoh kasus impor garam. KKP sebagai kementerian teknis terkesan tidak memiliki keterlibatan. Ini dikarenakan impor garam hanya menjadi pembahasan yang dilakukan Kemendag dan Kemenperin (Suhendra, 2011). Dalam kasus impor garam, Kemendag sejalan dengan Kemenperin yang mendukung kebijakan impor garam. Kemendag mengeluarkan aturan mengenai impor garam serta larangan-larangan waktu impor, karena garam adalah 
produk sensitif yang dilindungi pemerintah. Namun, larangan waktu impor ini sering dilarang oleh kementerian-kementerian pendukung impor garam ini. Kedua kementerian inipun tidak melibatkan KKP dalam membahas impor garam sehingga garam rakyat tidak terserap dengan baik karena kalah dengan garam impor.

\section{Kepentingan Aktor-Aktor Lain: Petani, Importir, dan Mafia}

Liberalisasi sektor garam di pasar domestik direalisasikan melalui penghapusan tarif impor, sehingga impor garam terus dilakukan tidak terlepas dari kepentingan aktor-aktor di luar birokrasi. Pertama, petani-petani garam baik yang tergabung dalam Asosiasi Petani Garam Indonesia atau tidak. Petani garam tidak mendukung impor garam yang dilakukan terus menerus karena dapat menyebabkan hasil produksi garam tidak dapat bersaing dipasaran. Apalagi didukung dengan kebijakan-kebijakan pemerintah terkait yang tidak bersinergi menyebabkan dukungan terhadap petani garam masih belum maksimal. Sebagai contohnya adalah petani-petani garam di Nusa Tenggara Timur yang mengeluhkan pemasaran yang berarti bahwa garam rakyat belum terserap dengan baik. Petani garam seperti ini merupakan pihak yang paling dirugikan dengan liberalisasi sektor garam di pasar domestik.

Kedua, importir garam yang tentu saja terus ingin melakukan impor garam. Aktor ini merupakan aktor yang diuntungkan dari liberalisasi sektor garam di Indonesia. Tarif impor garam hingga $0 \%$ ini membuat mereka dapat mengimpor dengan leluasa lalu menjualnya ke industri-industri yang membutuhkan garam sebagai bahan baku industri (Baihaki, 2013). Pemerintah yang mendukung untuk terus menerus mengimpor garam dinilai bekerjasama dengan importir garam. Hal ini dikarenakan keuntungan materi dari kebijakan impor garam ini akan dinikmati juga oleh pejabat pemerintahan. Importir garam sebenarnya diwajibkan untuk menyerap 50\% garam rakyat dari importasinya, tetapi hal ini tidak dilakukan bahkan stok garam milik importir masih banyak tersimpan di gudang-gudang pada tahun 2012 (Handoyo, 2012).

Ketiga, adanya mafia garam yang diyakini oleh mantan Menteri KKP, Fadel Muhammad, bahwa impor garam tetap dilakukan karena ada permainan mafia garam bukan karena kekurangan atau kualitas garam lokal yang buruk. Hal ini didukung dengan pernyataan Ketua Asosiasi Petani Garam (APG) Syaiful Rahman yang juga meyakini adanya mafia impor garam yang mana selama ini petani garam selalu dirugikan. Menurutnya, mafia impor sulit diberantas karena kebanyakan merupakan rekomendasi dari Kemendag dan Kemenperin. Ketua Dewan Tani Indonesia (DTI) Ferry Juliantono yang juga politisi partai Demokrat mendukung pernyataan ini bahwa memang ada mafia impor yang melibatkan pejabat Kemendag dan DPR (Rizal, 2011). Hal ini juga sejalan dengan Menteri KKP era Jokowi, Susi Pudjiastuti, yang mengatakan bahwa petani garam belum sejahtera karena ada permainan mafia garam. Pihak yang berwenang menjelaskan perihal mafia garam ini adalah Kemendag dan Kemenperin (Ernis, 2014).

Dari paparan di atas, penulis melihat bahwa terdapat dua dimensi kelompok kepentingan yang saling bertentangan (conflicting interest groups), yaitu kelompok kontra yakni KKP sejalan dengan Asosiasi Petani Garam Indonesia memiliki kepentingan untuk memberdayakan garam rakyat agar sedikit demi sedikit mengurangi impor garam. Sementara itu, kelompok pro impor garam terdiri dari Kemendag dan Kemenperin yang didukung oleh importir garam serta mafia garam. 


\section{E. Tarik Menarik Kepentingan Kelompok Birokrat Dan Kelompok Kepentingan}

Dalam pembuatan kebijakan, pembuat kebijakan selain berhadapan dengan tekanan internasional juga berhadapan dengan tekanan domestik menurut teori two-level games. Demikian juga dengan kebijakan liberalisasi sektor garam di pasar domestik ini dibuat untuk memenuhi kepentingan aktor-aktor domestik. Menurut governmental process, ada kelompokkelompok kepentingan yang berperan dalam pengambilan kebijakan oleh pemerintah untuk memenuhi kepentingan kelompok mereka. Pertarungan kepentingan di ranah domestik dalam kebijakan liberalisasi sektor garam melibatkan kelompok birokrat dan kelompok kepentingan. Kelompok-kelompok birokrat terdiri dari KKP, Kemenperin dan Kemendag. Sementara itu, kelompok kepentingan terdiri dari kelompok petani garam, importir garam dan mafia garam.

Kepentingan-kepentingan setiap aktor birokrat dapat dilihat dari bagaimana mereka membuat program-program tersendiri mengenai pemberdayaan industri garam tanpa ada koordinasi, sehingga hasil yang dicapai tidak maksimal. Data-data menunjukkan bagaimana setiap kementerian sebagai aktor-aktor yang berkaitan dengan urusan garam memiliki kepentingan masing-masing. KKP merupakan kelompok yang ingin memberdayakan garam rakyat melalui program PUGAR, namun tidak didukung dengan pengurangan impor garam sedikit demi sedikit oleh Kemenperin dan Kemendag yang berwenang. Garam rakyat diklaim Kemenperin masih belum memenuhi standar garam industri, sehingga impor garam menjadi keharusan. Namun di sisi lain, Kemenperin juga tidak melakukan koordinasi yang baik dengan KKP untuk dapat meningkatkan kualitas garam rakyat agar memenuhi standar garam industri. Di luar kelompok birokrat, kelompok kepentingan yakni importir dan mafia juga berusaha memenuhi kepentingan mereka dengan bekerjasama dengan pihak Kemenperin dan Kemendag. Sedangkan, kelompok petani garam, baik asosiasi maupun non asosiasi, bekerjasama dengan KKP guna mengurangi impor dan meningkatkan kualitas dan kuantitas produksi garam domestik.

Program PUGAR yang dijalankan idealnya didukung dengan teknologi industri agar menghasilkan garam industri yang berkualitas dan dengan pengurangan impor garam sedikit demi sedikit agar garam rakyat dapat berkembang. Namun pada kenyataannya, setiap kementerian memiliki program tersendiri yang tidak bersinergi. Hal ini terlihat pada program pemberdayaan garam yang juga dimiliki oleh Kemenperin namun tetap melakukan impor garam baik garam konsumsi maupun garam industri daripada memilih untuk melakukan transfer teknologi demi peningkatan produktivitas. Liberalisasi sektor garam ini melukai petani garam rakyat karena walau ada usaha pemberdayaan namun tidak didukung oleh kementerian lain yang terkait. Importir garam dan mafia garam sudah tentu mendukung liberalisasi sektor garam domestik ini karena mendatangkan keuntungan materi bagi kelompok mereka sehingga mereka terus berupaya untuk mempertahankan kebijakan ini dengan melakukan kerjasama dengan pihak kementerian.

Pada akhirnya, pertarungan kepentingan antara aktor-aktor yang pro impor garam (Kemenperin, Kemendag, importir dan mafia) dan yang kontra (KKP, kelompok petani garam) dimenangkan oleh yang pro terhadap impor garam. Kepentingan yang dimiliki aktoraktor pro impor garam ini juga sangat didukung oleh aktor-aktor internasional yang berasal dari W'TO, FTA dan IMF yang mengharuskan adanya liberalisasi perdagangan di Indonesia. 
Indonesia sudah meratifikasi perjanjian-perjanjian rezim-rezim tersebut menjadi beberapa undang-undang sehingga dalam konteks hukum internasional Indonesia memiliki kewajiban untuk mematuhi perjanjian-perjanjian tersebut. Penghapusan tarif sebagai bentuk liberalisasi perdagangan ini membuat garam impor membanjiri pasar domestik. Usaha dari aktor-aktor yang memiliki kepentingan terhadap pemberdayaan usaha garam rakyat pun menjadi tidak maksimal karena tidak didukung oleh aktor-aktor pro impor garam. Perbedaan kepentingan ini berujung pada kebijakan-kebijakan domestik yang tidak selaras mengenai komoditas garam. Disatu sisi, ingin memberdayakan garam rakyat, namun disisi lain impor garam terus dilakukan. Kebijakan yang bertolak belakang karena perbedaan kepentingan inilah yang membuat Indonesia pada akhirnya meliberalisasi sektor garam di pasar domestik.

Agar dapat mencapai swasembada garam nasional, maka tarik menarik kepentingan ini harus ditinggalkan dan mulai membuat kebijakan yang bersinergi antar setiap kelompok. Menurut Dinas Kelautan dan Perikanan Kupang (2014), hal-hal yang diperlukan untuk memudahkan tercapainya sinergitas di antara kementerian adalah kesamaan pemahaman, kesediaan untuk berbagi peran dan kekompakan serta kebersamaan. Ini merupakan hal yang tidak mudah karena kepentingan setiap kelompok selalu berbeda-beda. Selain itu, mengingat kebijakan diambil juga untuk memenuhi tekanan domestik maka kelompok kepentingan yang kontra pada impor garam harus lebih aktif dalam memengaruhi pemerintah.

\section{KESIMPULAN}

Liberalisasi sektor garam di Indonesia telah menyebabkan Indonesia sebagai negara maritim menjadi negara pengimpor garam. Pro dan kontra terhadap impor garam menjadi fenomena yang tidak terelakkan dalam proses politik domestik, baik dari kelompok birokrat maupun kelompok kepentingan di luar pemerintahan. Mereka memiliki kepentingan yang saling bertentangan. di kelompok birokrat, kurangnya atau bahkan tidak adanya koordinasi antara kementerian satu dengan lainnya untuk mensinergikan program-program yang berkaitan dengan garam menandai adanya pergolakan politik dalam pengambilan kebijakan.

Kelompok pro impor garam yang terdiri dari Kemenperin, Kemendag, importir dan mafia garam mendukung kebijakan impor garam dengan beberapa alasan yaitu kualitas dan kuantitas garam (khususnya garam industri) yang rendah, tuntutan pemenuhan kebutuhan garam domestik dan sebagainya. Sementara itu, kelompok kontra impor garam yang diwakili KKP dan petani garam baik dari asosiasi maupun non asosiasi menentang impor garam. Selain mengecam impor garam, KKP dengan PUGAR-nya berusaha memberdayakan petani garam domestik guna menghasilkan garam yang mampu memenuhi kebutuhan domestik baik kualitas dan kuantitas serta mendorong swasembada garam nasional. Tarik menarik kepentingan di antara dua kelompok tersebut dimenangkan oleh kelompok pro impor garam. Volume impor garam yang mengalami kenaikan dari tahun ke tahun. Sementara, produksi garam domestik khususnya garam industri juga masih belum memenuhi kualitas dan kuantitas yang diharapkan. 


\section{DAFTAR PUSTAKA}

Apriella, N. (2016). Dampak Program Pemberdayaan Usaha Garam Rakyat (pugar) Terbadap Strategi Nafkah dan Pendapatan Rumah Tangga Petambak Garam. Bogor: Institut Pertanian Bogor.

Arisanto, P. T., \& Pratiwi, T. S. (2020). Kebijakan Kriminalisasi LGBT Malawi Di Tengah Pengaruh Kelompok Kepentingan dan Politik Bantuan Luar Negeri. Jurnal Ilmiah Hubungan Internasional, 16(1). doi:https://doi.org/10.26593/jihi.v16i1.3297.69-86

Ariyanti, F. (2013, Oktober 14). Daftar Lengkap 29 Komoditas Pangan yang Dïmpor RI. Retrieved from Liputan6.com: https://bisnis.liputan6.com/read/719523/daftar-lengkap-29komoditas-pangan-yang-diimpor

Baihaki, L. (2013). Ekonomi-Politik Kebijakan Impor Garam Indonesia Periode 2007-2012. Yogyakarta: UGM.

Banton, C. (2019). Trade Liberalization. Retrieved from Investopedia: https://www.investopedia.com/terms/t/trade-liberalization.asp

Boenarco, I. S. (2012). Kebijakan Impor Garam Indonesia (2004-2010): Implikasi Liberalisasi Perdagangan Terhadap Sektor Pergaraman Nasional. Jakarta: Universitas Indonesia.

Cahaya, A. I. (2013). Kekayaan Laut Indonesia yang Galau. Retrieved from http://www.setkab.go.id/artikel6842-kekayaan-laut-indonesia-yang-galau.html

Detikfinance. (2012, September 14). Tabun Ini Indonesia Masib Impor Garam Konsumsi 495.000 Ton. Retrieved from detikfinance: https://finance.detik.com/industri/d2019133/tahun-ini-indonesia-masih-impor-garam-konsumsi-495000ton? $\mathrm{r} 771108 \mathrm{bcj}=\& \mathrm{r} 771108 \mathrm{bcj}=$

Diaz, J. P., \& Cho, S. W. (2008). Welfare Impact of Trade Liberalization. Australian School of Business Research Paper. No. 2008 ECON 20.

Ernis, D. (2014). Susi Tunjuk Lima Samurai sebagai Mafia Garam. Retrieved from Tempo.co: http://www.tempo.co/read/news/2014/12/08/090627058/susi-tunjuk-limasamurai-sebagaimafia-garam-nbsp

Faisal. (2014). Indonesia Masih Impor Garam Konsumsi Akibat Ada Yang Bermain. Retrieved from Poskotanews.com: http://poskotanews.com/2014/02/22/indonesia-masih-imporgaram-konsumsi-akibat-ada-yangbermain/

Fitria, A. G. (2014). Tabun Ini Indonesia Tak Perlu Impor Garam Konsumsi. Retrieved from Tempo.co: http://www.tempo.co/read/news/2014/01/29/090549228/Tahun-IniIndonesia-Tak-Perlu-ImporGaram-Konsumsi

Handoyo. (2014). PT Garam Monopoli Impor Garam. Retrieved from Kontan.co: https://industri.kontan.co.id/news/pt-garam-monopoli-impor-garam?

https://comtrade.un.org/

https://www.bps.go.id/

Irawan, A. (2011). Fadel dan Mari Pangestu "Berseteru" Gara-gara Garam Impor. Retrieved from Detik.com: http:/ finance.detik.com/read/2011/08/09/140147/1699958/4/fadeldan-mari-pangestu-berseterugara-gara-garam-impor

Jamil, A. S. (2015). Analisis Permintaan Impor Garam Indonesia. Bogor : Institut Pertanian Bogor. Kegiatan Fasilitasi Pertemuan Evaluasi Program DIT. PMPPU oleh Bapak Gumilar dari

Direktorat Pemberdayaan Masyarakat Pesisir dan Pengembangan Usaha (DIT.PMPPU)

Kementerian Kelautan dan Perikanan di Swiss-Belinn Kristal Hotel Kupang, 13 Oktober 2014.

Kementerian Perindustrian. (2009). Peta Panduan Pengembangan Klaster Industri Prioritas Industri Kecil dan Menengab Tertentu Tabun 2010-2014. Retrieved from http://rocana.kemenperin.go.id/index.php/download/category/1p?download $=6 \% 3 \mathrm{Ap}-\mathrm{p}$ 
Nurhayat, W. (2014). Pakai Lexus Temui Menteri Susi, Fadel: Tak Usah Kita Impor Garam. Retrieved from

Detik.com: http:// finance.detik.com/read/2014/11/10/164431/2744216/4/pakai-lexustemui-menteri-susifadel-tak-usah-kita-impor-garam?f9911023

Oatley, T. (2019). International Political Economy Sixth Edition. Longman: Pearson Education.

Observasi ke tambak garam milik Dinas Perindustrian dan Perdagangan Provinsi NTT di

Kecamatan Oesapa Barat pada 14 Oktober 2014 dan milik Dinas Perindustrian dan

Perdagangan Kabupaten Kupang di Desa Oeteta pada 24 Oktober 2014.

Peraturan Menteri Perdagangan Nomor 58/M-DAG/PER/9/2012

Peraturan Menteri Perindustrian No. 88/M-IND/PER/10/2014

Peraturan Menteri Perindustrian No.134/M.Ind/Per/10/2009

Putnam, R. D. (1988). Diplomacy and Domestic Politics: The Logic of Two-Level Games. International Organization, 42(3).

Raydion. (2012). Impor Garam Konsumsi: Terlalu Dini Kalau Ada yang Bilang Tidak Perlu. Retrieved from Bandung.com: http://bandung.bisnis.com/read/20120212/34231/143419/impor-garamkonsumsi-terlalu-dinikalau-ada-yang-bilang-tidak-perlu

Razif. (2012). Organisasi Terputus dengan Sejarah . Retrieved from Majalah Sedane: http://www.majalahsedane.net/2012/08/organisasi-terputus-dengan-sejarah.html

Rizal, M. (2011). Mafianya Justru Rekomendasi Kementerian. Retrieved from Detik.com: http://news.detik.com/read/2011/08/18/125127/1705899/159/1/mafianyajustru-rekomendasikementerian

Salima, A. R. (2016). Info Komoditi Gram: Badan Pengkajian dan Pengembangan Perdagangan. Jakarta: AMP Press.

Stiglitz, J. E. (2006). Making Globalization Work: Menyiasati Globalisasi Menuju Dunia yang Lebih Adil. New York: W.W. Norton \& Company.

Suhendra. (Detik.com). Impor Pangan Tersandra Kepentingan Banyak Mafia. Retrieved from http://finance.detik.com/read/2011/08/11/130659/1701489/4/impor-pangantersanderakepentingan-banyak-mafia

Truman, D. B. (1963). The Governmental Process: Political Interests and Public Opinion. New York: Borzoi Books.

Wawancara dengan Bapak Gumilar dari KP3K Kementerian Kelautan dan Perikanan RI di Kupang, 13 Oktober 2014.

Wawancara dengan Petani Tambak Garam Geomembran dan Konvensional di Desa Oeteta, Kecamatan Sulamu Kabupaten Kupang NTT pada tanggal 24 Oktober 2014. 